\title{
Evaluating the Effectiveness of Teaching Economics at the Senior High School Level
}

\author{
Emmanuel Baffour Gyau ${ }^{1 *}$, John Osei-Mensah ${ }^{2}$, George Amonoo ${ }^{3}$, Samuel Akowuah $^{4}$ \\ ${ }^{1}$ Institute of Science and Technology Information, Jiangsu University, Zhenjiang, China \\ ${ }^{2}$ Business Department, St. Louis Senior High School, Kumasi, Ghana \\ ${ }^{3}$ Social Science Department, Adisadel College, Cape Coast, Ghana \\ ${ }^{4}$ School of Management, Jiangsu University, Zhenjiang, China
}

\begin{abstract}
This study evaluates the effectiveness of teaching economics in some selected senior high schools in the Cape Coast municipality. The teaching of economics at the senior high school level seems to be beset with certain factors and these makes it difficult for teachers as they seek to improve the teaching of Economics in their role in nation building. The study therefore sought to find out how to improve the teaching of economics in the senior high school level. The study was conducted in the central region of Ghana with schools selected from the Cape Coast metropolis. Thirty (30) teachers from seven (7) senior high schools were used in the study. The convenience sampling technique was employed and to gather data, the questionnaire was the instrument used. Percentages and Frequencies were used to analyze the data. The research concluded that, majority of economics teachers are qualified with academic qualification of first degree, sufficient allocation on the time for teaching economics, inadequacy of teaching and learning resources, and teachers use more of the discussion method of teaching. To reduce, if not to eliminate, the factors that affect the effectiveness of teaching economics so as to improve teaching economics in the senior high school, adequate time, qualified teachers, teaching training and better methods of teaching should be employed to make teaching economics in the senior high more effective.
\end{abstract}

Keywords: Economics, effective teaching, senior high school, teacher, education

\section{INTRODUCTION}

$\mathrm{E}$ ducation is very important as far as every country's development and progress is concerned. Thus, contemporary development Economist attributes the wealth of nations to luck or education (learning) but learning is generally accepted to be sure way. Nations that assume to know everything already are likely to be pretty poor at learning with untold ripple effects on the economic growth and development. This assertion is supported by facts from countries such as Singapore, China, Malaysia and others who appear to develop at much faster pace than many countries owing to their affinity with learning even in the midst of intense scarcity of natural resources (Adelman, 2001). As education is the gateway to the development of every nation's human and capital resources, Ghana is not an exception. Some of the subjects that lead to the development of every nation's human and capital resources are Agricultural Science, Mathematics, Geography, Economics etc. Of all these subjects, the one which is of interest to the researchers is the teaching of Economics.

Every discipline taught in our schools has some form of historical development and challenges towards its inception and as such, Economics as a discipline cannot be exception. Economics as a discipline traces its history far back to the days of the mercantilists and the physiocrats but was not completely recognized until the classical era, when the Scottish economics philosopher, Smith (1776) made a dramatic advance in economics theory with "An inquiry into nature and causes of wealth of Nations". This breakthrough saw many countries modeling their economies to suit Smith's write up.

Other economists like Robbins, Keynes and Alfred Marshall contributed their quota in the subsequent years towards the development of the discipline. These contributions made many countries to consider introducing the discipline in their educational system. Pologeorgis (2002) and Harbury and Szreter (1970) added their voice in support of the study of Economics in secondary schools when they said that prior study of A level Economics does not at least appear to inhibit the success of the future undergraduate.

It took Ghana many years after the dust had settled to consider the introduction of Economics into the school curriculum. It was believed that economics had to do with miserliness and no parent was prepared to allow his or her child to be labeled a miser. The general public and the Ghana Education Service (GES) have come to accept the educational value of Economics. Economics is now offered as elective subject. Economics has now become an integral part of courses in some senior high school programmes like General Art, Business, Home economics and Visual Arts. In the Polytechnic, both tertiary and non-tertiary student pursing various programmes like National Diploma (HND), Diploma in Business Studies (DBS) and Institute of Chartered training, preparing for citizenships as well as vocational training.

With the introduction of the New Educational Reforms, the study and learning of Economics combines favorably with many more subjects at all levels. There is now a widespread acceptance of Economics as social science subject and this has consequently promoted the growth and development of various pedagogical skills and techniques of teaching 
Economics.

Notwithstanding the importance of economics to the Ghanaian society, the teaching of the subject is confronted with a number of factors and challenges which hinder the performance of students in their final results. This is evidence in the chef examiner's report of 2003 to 2007 and 2011 Economics results of West Africa Secondary School Certificate Examination (WASSCE). According to the report, there are some weaknesses which appear to run through all the results of student's performances in their final results. The following weaknesses were found occurring during the period.

1. Student's inability to apply the basics economic principles to explain situations or solve problems.

2. Some candidates were completely ignorant about the meaning of Economics terms and therefore gave irrelevant answers.

3. They were unable to use economic principles or points they rise to produce acceptable answers.

From the forgoing, it can be clearly seen that certain factors hinder the teaching of Economics in senior high school. It is against this background that this study has attempted to find out some of these factors in some selected senior high school in the Cape Coast Municipality. However, the teaching of economics has its own challenges just as the teaching of other subjects. According to the report, there are some weaknesses which appear to run through all the examinations. From the researchers' observation, it seems that the level of teacher motivation both intrinsic and extrinsic can influence effective teaching ((WAEC), 2003-2007; (WAEC), 2011; Council, 2010).

Teaching, like any task depends on the degree of motivation of the teacher. Also, the kind of environment in which teachers teach can affect effective teaching. If a particular kind of behavior can be attributed to the environment in which the organism develops, then, there can be a correlation between effective teaching and school or classroom environment.

Similarly, it appears standard textbooks on Economics are nonexistent. Teachers therefore seem to resort to pamphlets and sub-standard textbooks for reference. In plain language, the effect of such a phenomenon on the subject matter will be questionable. The study, therefore, aims at evaluating the effectiveness of teaching economics in senior high schools in the Cape Coast Municipality. From the researchers' observation, it seems: qualification of teachers, teaching learning resources, time allocation and methods of teaching of Economics are the factors affecting the status of teaching Economics. The research therefore seeks to find how these factors affect the effectiveness of teaching economics in the senior high school levels.

\section{Objective of the Study}

Generally, the study aims at evaluating the effectiveness of teaching economics at the senior high School level in the
Cape Coast Municipality. To achieve the main objective, the study therefore, aims specifically at finding answers to the following research questions

1. What are the qualifications of Economics teachers?

2. How adequate is the time allocated on the time table for teaching Economics?

3. To what extent are there relevant teaching learning resources for the teaching of Economics?

4. What are the predominant methods of teaching used by the Economics?

\section{LITERATURE REVIEW}

\section{Effective Teaching of Economics}

Teaching is often thought as something that comes through knowledge acquisition rather than naturally to people who know their subject. But teaching is an intriguing important and complex process. It takes place in a complicated social institution, which is filled diverse person. One cannot just know the subject and teach it because the subject themselves are ever changing (Atkins \& Brown, 2002).

The teacher must learn to control five processes of teaching namely;

1. Making and using knowledge

2. Shaping the school

3. Teaching with strategy

4. Creating impersonal climates

5. Controlling a teaching personality

According to Tamakloe et al. (2005), "Teaching is an activity of imparting knowledge, skills, attitudes and values to learners". It includes creating situations to facilitate learning and motivating learners to have interest in the lesson. Teaching does not occur without a supposed learner. According to their study since effective teaching depends to a large extent, on adequate preparation, it is important that the teacher gains good mastery of the subject matter of the topic which he intends to teach. On no account should the teacher take for granted that he has mastery of the subject matter. There is the need for him to revise what he thinks he already knows so as to refresh his memory and ensure accuracy. Teaching is said to be effective when the teacher employs theories, methodologies, principles, resources, etc. to impart knowledge to students in a more meaningful manner.

\section{Professional Qualification of Teachers}

The teacher is always seen as an important instrument in the teaching learning process. His presence, skills and experience are very important in the classroom work. The distinguishing nature of Economics and the abstract nature of some concepts and theories therefore demand a well-trained professional Economics teacher.

According to Rogers (2009), new and modernized curriculum may exist but without good teachers, it shall amount to nothing. It takes good teacher to produce good quality 
students. The report thus emphasized that professional qualification in teaching is very important and that every subject including Economics as an educational discipline deserves no less. Thus, for the teacher to make an impact on the learning behavior of students, his qualification, experience and his relationship with his students is of much concern.

According to Adentwi (2005), the executive model views the teachers as someone who has mastered the craft or technique of teaching and who sees his main responsibility to be to arrange the teaching and learning situation for learners to acquire a detailed knowledge of prescribed information and skills. This model of instruction sees the teachers as someone whose time-tested knowledge and special skills of handling the subject. Teaching therefore is identified as an interactive process of which the teacher possessing special skills to help free students minds by providing them with tools and attitudes necessary for learning. For that matter, Economics teachers are expected to be professionally trained for effective teaching and learning.

\section{Teaching-Learning Resources (TLRs)}

Teaching learning resources are resources that facilitate teaching by way of helping the teacher to explain and illustrate topics as this goes a long way to help students get clearer understanding of the lesson. Regardless of the teaching method used by the Economics teachers, there are a number of factors which can enhance his teaching and thereby assist in the teaching and learning process, one of such factors is the effective use of relevant teaching aids.

According to Tamakloe et al. (2005), however distinguish between teaching and learning resources, by stating that a teaching resource is a material which the teacher uses to facilitate the learning, understanding or acquisition of knowledge, concepts, principles or skills by his students while a learning resource is that which the student or a learner himself prepares and or uses to make learning easier than it would have been without. Thus, a teaching resource is what the teacher prepares or uses to make learning easier than it would have been without it. Therefore, in order to ensure an adequate and effective teaching, aids like chalkboards, duplicated materials, charts, pads, easels, forms and publication should be used to help make the students visualize the content of the work of the subject. The implication is that the teacher needs adequate and relevant resources provided by the school for him to carry out his work.

Fleming (2017) states that teaching learning resources are essential in promoting learning. He stressed that the use of audio, visuals and audio- visuals such as charts, diagrams, motion pictures, filmstrips, radio presentation, among others, arouse the interest and curiosity of students which motivates them to learn. Visual resources communicate their messages through the eyes. These materials include pictures, maps, diagrams, visual aids boards etc. A map is graphic symbolism which is use to present relief, physical features and the location of places as well as areas which are on the surface of the earth. For purpose of accuracy, maps are drawn to scale. Both accurate and sketch are of immerse importance in the teaching of Economics as it promotes effective teaching and learning. Audio aids are materials that provide information which can only be heard. These include gramophone, tape recorder and sound broadcast. Audio recordings must be such that they are audible and clear without interfering noise. Device such as cinematograph, television and video recorder are example of audiovisual resources. These aids when used appropriately are valuable because they provided sensory stimuli which give the students more accurate images than could be created verbally.

However, the environment particularly the community in which a school is established can serve as useful resource for teaching and learning. The teacher can invite several personalities from the community to deliver lectures or talks in Economics. The local bank manager, director of a firm, accountant, local tax collector or any prominent farmer could be invested to talk to the students on selected topics.

Research has also shown that most of the Economics books which are used in Ghanaian High Schools are written by foreigners and that situations used in such books do not reflect the situation of the Ghanaian economy.

\section{Methods of Teaching Economics}

The processes through which learning is effective is methods used. Ideally, this should be called teaching-learning methods but in the common parlance is "teaching method" (Tamakloe et al., 2005). By processes, we mean the methods of teaching are not a single event; rather, it consists of a series of activities and interactions adopted by the teacher to assist his students to learn a given learning task.

According to Heitzmann and Starpoli (1975), method refers to the "formal structure of the sequence of act commonly denoted by instruction". Each topic a teacher teaches can be naturally affiliated to given method of teaching taking consideration the age, interest, knowledge, experience of the students in question. The method used by the teacher in a lesson is the medium through which the teacher achieves his objectives.

Since learning is capable of taking place without teaching, it is therefore necessary to have a distinction between methods which are solely used for teaching. So, this clearly depicts that some methods of teaching Economics to students appear to be more effective than other in some situations hence the need for different methods of teaching Economics. The justification of the use of various teaching methods is evidenced in the view of the above statement hence below are the various methods of teaching.

\section{Lecture Method}

The lecture method is regarded as one the oldest method of teaching. It originated as a result of the difficult or expensive way of book production and this made books to be very scarce 
and for that matter, people did not have access to books. This made scholars who were concerned about this problem took upon themselves to make people get access to information and through this, the use of the lecture method was established. The method is dominated by teacher; thus, the teacher does most of the talking. According to Lowman and Lowman (1984), the various forms of lecture methods are "formal oral essay", "provocation lecture", "lecture demonstration", "question lecture", and "lecture recitation". These show that the role of the student in the lecture method is more passive in the teaching process.

\section{Discussion Method}

Meyers (1986), states that, discussion method is "used in engaging students' interest, challenging students, presenting thinking process and creating the atmosphere where active reflection and interchange replace caution and passivity". It demands a great deal of reflective thinking on the part of students and methods is very slow in achieving goals or thinking nature of students.

Nacino-Brown et al. (1982), state that, "discussion is treated as an overall step by step procedure of teaching a specific aspect of subject or a course on other to achieve definite instructional goals". From the above definitions, discussion method is seen to take place among and between the students with the supervision of the teacher to achieve his objectives. (Gall, 1984; Wilen, 1990), suggest that the discussion method should be used frequently.

Teachers' effectiveness in teaching Economics is better enhanced when the discussion method is used. In the discussion method, since it mostly involves students, the teacher is able to solicit different ideas or views from the students which help him to identify the loop-holes or problems faced by students. In class and group discussion, student's active participation in teaching and learning process which will intend help edify the behaviors and attitudes of student through critical analysis and thinking. This will also help them apply the concepts and principles of Economics in their real lives.

\section{Field Trip}

Field trip is a well-organized trip to places of interest that will facilitate teaching process to achieve its objectives outside the classroom such as factories, universities, supermarket, shops, etc. This shows that field trips can take place within the school environment (local field work) or outside (distant field work). With reference to Tamakloe et al. (2005), field trip can be categorized into two main types, that is, structured and unstructured field trips. These categories help students in the understanding of the lesson.

According to Nacino-Brown et al. (1982), field trips provide a sound and concrete basis for conceptualization. Through field trips students are exposed to the realities of life and the pictorial view that they got out of what they see help them to apply some of the concept and principles of Economics. For instance, when students are exposed to the market, they get to know market forces that determine the price.

\section{Problem Solving Method}

Problem solving method, in modern terms can be defined as a "planned attack upon a difficulty for the purpose of finding solution(s). It is a method in which a person uses his ability to solve problems which confronts him or her" (Aggarwal \& Jca, 2009). This appears that in problem solving method, the student is guided to solve practical or real problems worrying his or her society. Emphasis is most at times placed on concrete findings or solutions to problems which in the long run help the students to think abstract.

\section{Role Play}

Role play is a method in which students assume the role certain personalities in an organization and act out scenes that depict certain economic principles or concepts. Cannon (1987), defines role play as, "dramatizing of a situation by a number of students under the direction of the teacher with the sole purpose of understanding the feeling, action and behavior of others, especially in a problem situation".

According to Farrant (1964), demonstration method involves the teacher showing how something is done for the children to imitate. Groenewegen (1995), also support the view that demonstration is based on imitation by saying that the method is based on the assumption that by seeing exactly what takes place, the students will learn more effectively. He observes that methods permit firsthand experience in the operation of equipment, gives student a model to imitate.

\section{Time Allocation for Economics}

Apportioning of time is very vital in the daily routines of individuals so is the allocation of time to the teaching of Economics in senior high schools. The teacher therefore needs enough time to carry out the teaching activity effectively since the senior high school Economics syllabus is very demanding. The syllabus and the time table are therefore of much importance in the teaching of Economics.

Dotse (1984), contends that time factor is one of the most important factors to be considered in planning a syllabus. This is because it decides the length of the period of study which can be changed. The length of the period of study shows how much can be covered within a particular period. The inadequate time allotted on the time table for Economics therefore means that there cannot be any meaningful teaching and that the teacher cannot complete the syllabus before the final examination.

Also, due to individual differences, all students do not learn at the same rate; some students learn faster than others. Slow learners should therefore be given ample time to master the subject which the time table does not permit such demands considering the number of topics to be treated per term and the time allotted to the teaching of those topics (Kuethe, 1968). 
Anderson and Block (2014), stated that sufficient time should be assigned to each of the component into which an educational programme is divided to permit all the student in the programme to master it up to a pre-determined level. They suggest that students who learn slowly should be given special attention for them to comprehend. The fact that some students learn slowly suggest a need to examine the syllabus and the period allocated for the study of Economics to ensure that some students are not put at a greater disadvantage.

In the words of Howes (1974), "there is no hard and fast rule about how much time should be spent but the need to be guidelines that would help to stimulate thinking so that the teacher plans how time is to be spent rather than being a slave to the happening". What matters according to him is for teachers to use time effectively.

According to Dare (1995), inadequate time allotted to Economics prevents the students from having practical and going on field trips but these activities are essential for helping the students to acquire in depth knowledge and understanding the material presented during lesson that is vital for effective learning.

Given the entry behavior and the workload in the syllabus for senior high school Economics, Dare (1995), contends that the time frame is too short and suggests a pruning of the syllabus. He supports his argument with the call by the Conference of Heads of Assisted Secondary Schools (CHASS) for an increase in the duration of the Senior High School to four years as published in the People's Daily Graphic, February 17, 1993 (p.1) (L., 1993). To Dare, students are presented economic concepts and are not taught.

From the forgoing, time management as well as time allocation is vital in teaching. As we allow for some degree of flexibility in this arena, it behooves on us to remain in spirit job accomplishment by making maximum use of contact hours and ensuring that adequate time is allotted to the teaching of Economics which enhance effective teaching of it.

\section{METHODOLOGY}

The study adopted the descriptive research design. To Rubin and Babbie (2016), descriptive studies seek to portray accurately the characteristics of a population attempting usually to make generalizations about the attributes of that population. They noted that where there is confidence that the sample is representative of the population, descriptive studies is the most appropriate. The descriptive survey determines and reports the way things are (Wallen \& Fraenkel, 2013). Where there is confidence that the sample is representative of the population, the descriptive survey is the most appropriate.

The population is made up of the target population and the accessible population. Rubin and Babbie (2016), defines a population as "the theoretically specified aggregation of study element". The target population is all senior high school teachers in the Cape Coast Municipality. However, the accessible population was Economics teachers from seven schools which were selected based on convenience. A sample of thirty (30) Economics teachers was used in the study and selected from these seven schools. The number of Economics teachers ranged from one (1) to eight (8) in the school selected for the study. It proper to study the whole population if the population size is small. To this, all the Economics teachers in the selected schools were used for the study which was made up of eight (8) teachers from A.M.E Zion Aggrey Memorial Senior High School, five (5) teachers from St Augustine's College, four (4) teachers from Oguaa Secondary Technical, four (4) teachers from Academy of Christ the King, four (4) teachers from Mfantsipim Senior High School, four (4) teachers from Sammo Senior High School, one (1) from workers college. Table 1 depicts the distribution of the teachers according to their schools.

Table 1: Number of Sampled Teachers from Schools

\begin{tabular}{|c|c|c|}
\hline Name of School & $\begin{array}{c}\text { Respondents } \\
\mathrm{n}\end{array}$ & $\begin{array}{c}\text { Respondents } \\
\%\end{array}$ \\
\hline $\begin{array}{c}\text { A.M.E Zion Aggrey Memorial Senior } \\
\text { High School }\end{array}$ & 8 & 26.7 \\
\hline St. Augustine's College & 5 & 16.7 \\
\hline Oguaa Secondary Technical School & 4 & 13.3 \\
\hline Academy of Christ the King & 4 & 13.3 \\
\hline Mfantsipim Senior High School & 4 & 13.3 \\
\hline Sammy Otoo Senior High School & 4 & 13.3 \\
\hline Workers College & 1 & 3.3 \\
\hline Total & 30 & 100 \\
\hline
\end{tabular}

Note: $\mathrm{n}$ and $\%$ represent the number of respondents for each question and the percentage of the respondents respectively. Authors compilation.

All Economics teachers in the 7 schools were selected for the study. This represents $100 \%$ of the population. The researchers used the census sampling method.

The instrument for the data collection was the questionnaire. When questionnaire is employed in gathering data, there is lack of interviewer bias and there is the possibility of anonymity and privacy which encourages more candid responses (Rubin \& Babbie, 2016). It was made of two sections. Section A contained the bio- data seeking to find out the background information of the teachers. The background information of the teachers included gender and age. Section $\mathrm{B}$ dealt with the factors affecting the teaching of Economics and was made up of four sub-sections. This included their academic qualifications, professional qualifications and it had five (5) items. Sub-Section B was devoted to time allocation on the time table and it had (6) items. Sub section C dealt with the teaching learning resources and had three (3) items. Lastly, sub-section D contained methods of teaching and had six (6) items. But the last item in this section was an openended question which was for the respondents (teachers) to specify other methods used in teaching Economics.

An introductory letter from the head of department was sent to 
the various heads of the selected senior high schools by the researchers. The heads of the selected senior high schools then introduce the researchers to the Economics teachers and the questionnaires were administered to them. The answered questionnaires were collected on the date agreed upon with the respondents. The response rate was 100 percent. The collected data were edited, coded and analyzed. The Statistical Package for Social Sciences (SPSS version 25.0) was used in the analysis. Descriptive statistics was used to analyze the data from the questionnaires and frequency tables were used to analyze each item. To measure the direction of the responses, percentages and frequencies were used.

\section{RESULTS AND DISCUSSION}

The study uses mainly frequencies tables as tools for its analysis. In the tables, provisions are made for the respondents' frequency as well as the corresponding percentages. To cater for research objectives which drive the entire paper, the objectives are cast into headings and sub headings. By implication, all results connected to each research question are analyzed and discussed thoroughly within the framework of the objectives of the study outlined explicitly in the study.

\section{Background information of teachers}

The variables dealt with under this section include gender and age. Table 2 presents the summary of the response on gender and age of teachers. The data collected indicated that 28 (93.3\%) of the respondent were male teachers whereas 2 (6.7\%) were female teachers. From table 2 above, it can therefore be said that more of the Senior High School Economics teachers in the Cape Coast Municipality are males as compared to their female counterparts. This may be due to the mind-set of most females about Economics at higher levels. It is always perceived that Economics at higher level is difficult and as such, most females become afraid to further it at the tertiary levels. The age of Economics teachers was also looked at. The ages were put into ranges from 25 and below to 46 and above. From Table 2, out of 30 respondents, 6 (20\%) fell within 25 years and below.

Also, $5(16.7 \%)$ of the respondents were between the ages of 26-30, 31-35 and 41-45 years. Moreover, 7 (23.3\%) of the respondents were between $36-40$ years and the remaining 2 $(6.7 \%)$ of the respondents were also of the ages of 46 and above. This implies that, majority of Economics teachers in Cape Coast Municipality are between the ages of 36-40 years whiles few of the teachers are between the ages of 46 and above as shown in table 2. This implies that, the senior high school. in the Cape Coast Municipality are more interested in the young and energetic teachers who are believed to be well abreast in current curriculum in the teaching of Economics.
Table 2: Gender and age of teachers

\begin{tabular}{|c|c|c|c|}
\hline Variables & Characteristics & $\begin{array}{c}\text { Respondents } \\
\mathrm{n}\end{array}$ & $\begin{array}{c}\text { Respondents } \\
\%\end{array}$ \\
\hline Gender & Male & 28 & 93.3 \\
\hline & Female & 2 & 6.7 \\
\hline Age & 25 and below & 6 & 20.0 \\
\hline & $26-30$ years & 5 & 16.7 \\
\hline & $31-35$ years & 5 & 16.7 \\
\hline & $36-40$ years & 7 & 23.3 \\
\hline & $41-45$ years & 5 & 16.7 \\
\hline & 46 years and above & 2 & 6.7 \\
\hline
\end{tabular}

Note: $\mathrm{n}$ and \% represent the number of respondents for each question and the percentage of the respondents respectively. Authors compilation.

\section{Qualification and Experience of Teachers}

The study also aimed at finding out the academic qualification, professional qualification and teaching experience of teachers handling the subject Economics at the Senior High School level and how this affects effective teaching of Economics. Table 3 presents the results and it shows that, $28(93.3 \%)$ of the respondents were first degree holders and $2(6.7 \%)$ were also master degree out of the total respondents. A careful examination of the table shows that, majority of Economics teachers at the Senior High School level at the Cape Coast Municipality are holders of first degree with a few of them being master holders. Also, out of the 30 respondents none of them had ' $A$ ' level qualification or any other academic qualification. This finding also corroborated Harris and Sass (2009) who observed that teachers experience and qualification has a significant effect on students' achievement in English language. In line with this, Strauss and Vogt (2001) were of the opinion that teachers teaching qualification and experience are strong determinants of student academic achievements. Ojo (2008) supported this in their findings that teachers' qualification and experience, among others affected the performance of the students in English language. Apart from the academic qualification of Economics teachers in the Senior High Schools, the researchers wanted to find out the professional qualification of these teachers, thus, if they have undergone any training relating to the teaching and learning of Economics. The results showed that, graduate education had larger proportion of the respondents that is $19(63.3 \%)$. The table further illustrated that $7(23.3 \%)$ of the respondents had Diploma education and the remaining $4(13.3 \%)$ of the respondents had other qualifications. For the other professional qualifications, one had Certificate 'A', 3 years post-secondary and the remaining two had no professional qualification in education. The table shows that, more or majority of Economics teachers in the Cape Coast Metropolis is professionally qualified. Thus, having 19 of them having graduate education and 7 of them having diploma education. A few of them are not professionally qualified, thus 2 of them but undergrounding 
their professional education. This finding confirms the findings by the research conducted by Adentwi and Sarfo (2005) that the executive model views teachers as someone who has mastered the craft or technique of teaching and learning situation for learners to acquire a detailed knowledge of prescribed information and skills. This model of instruction sees the teacher as someone whose time-tested knowledge and special skills of handling the subject. For that matter, Economics teachers are expected to be professionally trained for effective teaching and learning. Moreover, researchers went on to find out the number of years of teaching Economics in the Senior High School. This was to find out the teaching experience teachers have acquired in the teaching of the subject. According to the results, out of the 30 respondents, $12(40.0 \%)$ of them have taught Economics for between 1-4 years and $9(30.0 \%)$ of them between 5-8 years. Another 4 (13.3\%) of the respondents had taught Economics for between 9-12 years and 13-16 years. The remaining 1 (3.3\%) respondent had taught Economics for 17 years and above. By implication, majority of the teachers have had enough or average number of teaching experience relative to the population of Economics teachers.

Table 3: Qualification of teachers

\begin{tabular}{|c|c|c|c|}
\hline Variables & Characteristics & $\begin{array}{c}\text { Respondents } \\
\mathrm{n}\end{array}$ & $\begin{array}{c}\text { Respondents } \\
\%\end{array}$ \\
\hline $\begin{array}{c}\text { Academic } \\
\text { Qualification }\end{array}$ & Masters & 2 & 6.7 \\
\hline & Bachelor's degree & 28 & 93.3 \\
\hline $\begin{array}{c}\text { Professional } \\
\text { Qualification }\end{array}$ & Graduate Education & 19 & 63.3 \\
\hline & Diploma Education & 7 & 23.3 \\
\hline & Other & 4 & 13.3 \\
\hline $\begin{array}{c}\text { Teaching } \\
\text { Experience }\end{array}$ & $1-4$ years & 12 & 40.0 \\
\hline & $5-8$ years & 9 & 30.0 \\
\hline & 13 - 16 years & 4 & 13.3 \\
\hline & 17 years and above & 4 & 13.3 \\
\hline & & 1 & 3.3 \\
\hline
\end{tabular}

Note: $\mathrm{n}$ and $\%$ represent the number of respondents for each question and the percentage of the respondents respectively. Authors compilation.

\section{Training of teachers}

Apart from the teaching experience gained by teachers, the researchers also determined whether teachers had any inservice training and how regular is the training in the teaching of Economics. Table 6 presents the summary of the results. Table 6 showed that $26(86.7 \%)$ of the respondent said No, they had no in- service training in Economics whiles 4 $(13.3 \%)$ said Yes. It is clear that a vast number of Economics teachers do not undertake any in-service training. But according to Antwi (1993), professions tend to demand high professional conduct of their members in the outside world. Thus, doctors of medicine, priest and lawyers all have their oath. In addition, ethical code controls the behavior of professionals. The researchers also wanted find out how regular teachers had in-service training in Economics. Table 7 presents the summary of the results.

From Table 7, it can be noticed that those who said yes had in-service training and had it very often is only1 (3.3\%). Also, $3(10.0 \%)$ of the respondents had in-service training not often. In contrast, those respondents who said no they has on inservice training chose No and they are $26(86.7 \%)$ out of the total respondent. This implies that even though some of the respondents had in-service training in Economics, it is not often. This finding undermines profession ethical codes drawn by the Ministry of Education to guide the conducts of all teachers. According to the Ministry of Education, to gain professional qualification and teaching experiences, there should be regular in-service training for professional Economics teachers. This finding is contrary to a study by Swinton et al. (2010) titled, does in-service professional learning for high school economics teachers improve student achievement. They concluded that, a positive and significant impact of teacher workshop attendance, once teachers have attended three workshops on student test scores. Furthermore, the results suggest that in-service workshops for economics teachers offer a cost-effective way to provide content training.

Table 4: Training of teachers

\begin{tabular}{|c|c|c|c|}
\hline Variables & Characteristics & $\begin{array}{c}\text { Respondents } \\
\mathrm{n}\end{array}$ & $\begin{array}{c}\text { Respondents } \\
\%\end{array}$ \\
\hline $\begin{array}{c}\text { In-service } \\
\text { Training }\end{array}$ & Yes & 4 & 13.3 \\
\hline $\begin{array}{c}\text { Regularity of In- } \\
\text { Service Training }\end{array}$ & No & 26 & 86.7 \\
\hline & Not often & 1 & 3.3 \\
\hline & Never & 26 & 10.0 \\
\hline
\end{tabular}

Note: $\mathrm{n}$ and \% represent the number of respondents for each question and the percentage of the respondents respectively. Authors compilation.

\section{Time Allocation for Teaching Economics}

The study also presents the results on how adequate is the time allocated on the time table for teaching Economics by considering number of classes a teacher teaches, period of teaching per week and duration of teaching period. The results as shown in table 4 depicts that, $17(56.7 \%)$ teach 18 period per week. $13(43.3 \%)$ of the teachers of Economics in the Cape Coast Municipality teach between 18 period and above. This implies that teachers who teach below 18 periods are more than those who teach above 18 periods. This finding confirms the findings of a research conducted by Dotse (1984), that time factor is one of the most important factors to be considered in planning a syllabus. This is because it decides the length of the period of study which can be changed. The length of the period of study shows how much can be covered within a particular period. The inadequate time allotted on the time table for Economics therefore means that 
there cannot be any meaningful teaching and that the teacher cannot complete the syllabus before the final examination.

Apart from the number of teaching periods per week by teachers, the researchers wanted to find out the duration of teaching. Table 9 presents the summary of the results. The findings also showed that, $5(16.7 \%)$ of the respondents teach 35 minutes each period and $21(70.0 \%)$ of teachers teach 40 minutes each period. And the remaining 4 (13.3\%) respondents teach 45 minutes each period. This depicts that, teachers in the Senior High School in the Cape Coast Municipality have enough time to teach each period.

It also interests the researchers to find out whether time on the time table for each period is sufficient for teaching. From the table, it can be deduced that, $2(6.7 \%)$ of respondent strongly agree, $25(83.3 \%)$ of them agree and the remaining $3(10.0 \%)$ of the respondents disagree that the time allocated on the time table for each period is sufficient. This shows that most of the teachers in Cape Coast Metropolis at the senior high school level agree that time allocation is sufficient for each period where as few of them disagree. This is contrary to a study by Mabusela (2018), on the challenges of curriculum changes in teaching economic and management sciences in schools in the Umhlathuze circuit. The study concluded that the time allocated to teach economic and management sciences is not enough which causes teachers to focus on curriculum coverage rather than ensuring that learners master the content taught.

The number of classes each Economics teachers were also taken into consideration by the researchers. With regard to the number of classes being taught by each teacher, it came to light that $1(3.3 \%)$ of the respondent teaches one of the classes; $3(10.0 \%)$ of the respondents teach two classes and 15 $(50 \%)$ of the respondents teach more than 3 classes. Out of 15 of the respondents who teach more than 3 classes, 10 of them teach 4 classes, 3 of them teach 5 classes, 1 teaches 6 classes and the remaining 1 respondent teaches 7 classes. This shows that, more of the Economics teachers in the Cape Coast Metropolis at the S.H.S level teach more than 3 classes. This will reduce the effectiveness of the teacher because the teacher becomes more exhausted more from one class to another and preparing for more than three (3) classes in a day. Also, there would be pressure and burden on the teacher in marking of class exercises.

The researchers went on find out whether teachers were able to cover the syllabus for the term. The outcome realized from the responses indicated that $22(73.3 \%)$ of the respondents said they are able to cover the syllabus for the term whereas the remaining $8(26.7 \%)$ respondents said they are not able to cover the syllabus for the team. This shows that more of the teachers in the Cape Coast Metropolis at the senior high school level are able to cover the syllabus for the term and few of them are not. It was realized that not all the teachers were able to cover the syllabus for the term. The reasons why some teachers were not able to cover the syllabus for the term were that, out of the $8(26.7 \%)$ respondents who are able to cover the syllabus for the term, 5 of them attribute it to frequent interruptions by holidays and sporting activities and slow responses of students in classroom lessons. One of them said the nature of the syllabus is too broad and no reliable textbook for Economics. Another respondent said some topics are difficult to understand and it takes a longer time to explain and the last respondent attributed his reasons to limited time duration.

Table 5: Time Allocation for teaching

\begin{tabular}{|c|c|c|c|}
\hline Variables & Characteristics & $\begin{array}{c}\text { Respondents } \\
n\end{array}$ & $\begin{array}{c}\text { Respondents } \\
\%\end{array}$ \\
\hline \multirow{2}{*}{$\begin{array}{c}\text { Period of } \\
\text { teaching per } \\
\text { week } \\
\end{array}$} & Below 18 periods & 17 & 56.7 \\
\hline & Above 18 periods & 13 & 43.3 \\
\hline \multirow[t]{3}{*}{$\begin{array}{c}\text { Duration of } \\
\text { Teaching Period }\end{array}$} & 35 minutes & 5 & 16.7 \\
\hline & 40 minutes & 21 & 70.0 \\
\hline & 45 minutes & 4 & 13.3 \\
\hline \multirow[t]{3}{*}{$\begin{array}{c}\text { Sufficiency of } \\
\text { Time Allocation }\end{array}$} & Strongly Agree & 2 & 6.7 \\
\hline & Agree & 25 & 83.3 \\
\hline & Disagree & 3 & 10.0 \\
\hline \multirow[t]{4}{*}{$\begin{array}{c}\text { Number of } \\
\text { Classes a } \\
\text { Teacher Teaches }\end{array}$} & One & 1 & 3.3 \\
\hline & Two & 3 & 10.0 \\
\hline & Three & 11 & 36.7 \\
\hline & Four and above & 15 & 50.0 \\
\hline \multirow[t]{2}{*}{$\begin{array}{c}\text { Coverage of } \\
\text { Syllabus for a } \\
\text { Term }\end{array}$} & Yes & 22 & 73.3 \\
\hline & No & 8 & 26.7 \\
\hline
\end{tabular}

Note: $\mathrm{n}$ and \% represent the number of respondents for each question and the percentage of the respondents respectively. Authors compilation.

\section{Teaching Learning Resources}

The findings on determining to what extent there are relevant teaching learning resources for the teaching of Economics showed that, $27(90.0 \%)$ of the respondents use diagrams and sketches, $1(3.3 \%)$ of the respondent uses textbooks whiles the remaining 2 respondents use chart illustrations. By implication, majority of the Economics teachers at the senior high school level in the Cape Coast Municipality use diagrams and sketches to aid the teaching of Economics whiles few of them uses textbook and board illustration as shown in table 6 . Mabusela (2018), concluded in their study on the challenges of curriculum changes in teaching economic and management sciences in schools in the Umhlathuze circuit that, shortage of textbooks and calculators was also identified as a major challenge in many schools and there is a need for sufficient 
resources in schools to ensure effective teaching and learning.

Furthermore, the researchers wanted to find out how often teachers use these teaching aids and the results showed that 7 $(23.3 \%)$ of the respondents use these teaching aids always, 21 $(70.0 \%)$ of the respondents use the teaching aid occasionally and $2(6.7 \%)$ of them do not often use the teaching aids. This means that most of the teachers in the Cape Coast Municipality at the senior high school level use teaching aids occasionally and a few of them do not often use teaching aids. This authenticates the findings of Fleming (2017), that teaching learning resources are essential in promoting learning. He stressed that the use of audio, visuals and audiovisuals such as charts, diagrams, motion pictures, filmstrips, radio presentation, among others, arouse the interest and curiosity of students which motivates them to learn.

It also interests the researchers to find out how convenient teachers find the use of the teaching aids. Table 6 shows that, $24(80.0 \%)$ of the total respondents find the teaching aids convenient, $6(20.0 \%)$ of the respondents see the teaching aids to be very convenient and none of the respondents find the teaching aid not convenient. This implies that, almost all the teachers in the Cape Coast Municipality at the senior high school level find the teaching aids they use convenient. This finding is contradicts a study by Adjei et al. (2013) the impact of teaching learning resources on teaching business management. The concluded that teachers' use of teachinglearning resources often was not convincing. that most schools in the Suame District of the Kumasi Metropolis had teachinglearning resources to aid them in the teaching-learning process, and interestingly, most teachers did not use them.

Table 6: Teaching learning resources for teachers

\begin{tabular}{|c|c|c|c|}
\hline Variables & Characteristics & $\begin{array}{c}\text { Respondents } \\
\mathrm{n}\end{array}$ & $\begin{array}{c}\text { Respondents } \\
\%\end{array}$ \\
\hline $\begin{array}{c}\text { Teaching Aids } \\
\text { Employed by } \\
\begin{array}{c}\text { Economics } \\
\text { Teachers }\end{array}\end{array}$ & $\begin{array}{c}\text { Diagrams and } \\
\text { Sketches }\end{array}$ & 27 & 90.0 \\
\hline & Textbooks & 1 & 3.3 \\
\hline $\begin{array}{c}\text { Frequency of use } \\
\text { of Teaching Aids } \\
\text { by Economics } \\
\text { Teachers }\end{array}$ & Always & 2 & 6.7 \\
\hline & Occasionally & 21 & 23.3 \\
\hline $\begin{array}{c}\text { Not Often } \\
\text { Teaching Aids }\end{array}$ & Convenient & 24 & 60.0 \\
\hline & Very Convenient & 6 & 20.0 \\
\hline
\end{tabular}

Note: $\mathrm{n}$ and $\%$ represent the number of respondents for each question and the percentage of the respondents respectively. Authors compilation.

\section{Method of Teaching}

In addition, the predominant methods of teaching used by the
Economics teachers at senior high school level was also assessed and the results as shown in table 7 depict that, 11 $(36.7 \%)$ of the respondents responded that, they use the lecture method often, $13(43.3 \%)$ responded that the lecture method of teaching is used seldom and remaining $6(20.0 \%)$ responded that they never use the lecture method of teaching. According to Baynham and Trump (1961), teachers use interactive lecture method in the secondary schools. This is done by involving students through the use of questions during and after the presentation. This affirms a study by Danaei et al. (2011), which method of teaching would be better; cooperative or lecture?. Where they concluding by saying that most of the knowledge acquired through lecturing is forgotten rapidly. Hence, while it is seldomly used by teachers.

Also, aside the lecture method of teaching, the researchers also wanted to find out how often teachers use the discussion method of teaching. $26(86.7 \%)$ of the respondents said they use the discussion method and $4(13.3 \%)$ of the respondents seldom use the discussion method. This means that majority of the teachers in Cape Coast Municipality use the discussion method. This can be seen from the work of Nacino-Brown et al. (1982) that, discussion is treated as an overall step by step procedure of teaching a specific aspect of subject or a course on other to achieve definite instructional goals. From the above definitions, discussion method is seen to take place among and between the students with the supervision of the teacher to achieve his objectives. Also confirming that, the lecture/discussion teaching method is the most preferred among students according to a study by Carpenter (2006) on effective teaching methods for large class.

The researchers also found out the use of the role play method of teaching. From the results, it can be deducted that, $2(6.7 \%)$ responded often to the use of role play method, $21(70.0 \%)$ responded seldom to the use of role play method, and the remaining $7(23.3 \%)$ of them responded they never use the role play method.

The use of the problem solving as a method of teaching were taken into consideration by the researchers. In relation to the use of the problem-solving method of teaching, $20(66.7 \%)$ of the respondents use the method and 10 (33.3\%) of the respondents seldom use the problem-solving method of teaching. This means that majority of the teachers in the Cape Coast Metropolis often use the problem solving. This finding confirms a study by Behlol et al. (2018), who studied effectiveness of problem solving method in teaching Mathematics at Elementary Level and found problem solving method to be more effective and recommend it to used teachers for teaching and making lesson plans

Furthermore, the researchers wanted to find how often teachers use the fieldtrip method of teaching. Table 7 further illustrated that, $3(10.0 \%)$ of the respondents seldom use the field trip method of teaching and the remaining $27(90.0 \%)$ of them never use the field trip method of teaching. This depicts 
that majority of the teacher in the Cape Coast Municipality at the senior high school level do not use field trip method of teaching which according to Nacino-Brown et al. (1982) provides a sound concrete basis for conceptualization. A study by Mabusela (2018), concluded that, teachers should use a variety of teaching strategies and should adapt their teaching practice as a result of curriculum change

Table 7: Method of Teaching

\begin{tabular}{|c|c|c|c|}
\hline Method & Often & Seldom & Never \\
\hline \multirow{2}{*}{ Lecture } & 11 & 13 & 16 \\
& $36.7 \%$ & $43.3 \%$ & $20.0 \%$ \\
\hline \multirow{2}{*}{ Discussion } & 26 & 4 & \\
& $86.7 \%$ & 13.3 & \\
\hline \multirow{2}{*}{ Role play } & 2 & 21 & 7 \\
& $6.7 \%$ & $70 \%$ & $23.3 \%$ \\
\hline \multirow{2}{*}{ Problem Solving } & 20 & 10 & \\
& $66.7 \%$ & $33.3 \%$ & \\
\hline \multirow{2}{*}{ Field Trip } & & 3 & 27 \\
& & $10.0 \%$ & $90.0 \%$ \\
\hline
\end{tabular}

\section{CONCLUSIONS}

The research conducted shows that, more of the teachers teaching Economics at the Senior High School level have academic qualification of first degree and most of them having graduate education as their professional qualification. It can therefore be concluded that most Economics teachers at the senior high school are well qualified to teach the subject.

Majority of teachers agreed that time allotted for teaching Economics is sufficient for them to ensure adequate coverage of the syllabus. Therefore, it can be concluded from the study that Economics teachers have enough time at their disposal to complete the syllabus.

It was noted that though the teachers use various method of teaching, the discussion method is frequently used. Thus, majority of teachers resort to this method.

The research revealed that recommended Economics teaching resources like text books for the effective teaching of the subject is insufficient or not available for use by both students and teachers.

\section{RECOMMENDATIONS}

According to the findings of the research, the following recommendations were made.

With regard to the reliance on a single method of teaching, Ghana Education Service (GES) should organize workshops, in-service training and seminars on the various methods of teaching to upgrade the knowledge of teachers on the new concepts and principles, and teaching skills for effective delivery of the subject. Periodic in- service training at the schools, Metropolis and Regional levels would go a long to enhance the effective teaching of the subject.

Also, the Economics Teachers Association of Ghana (ETAG) serves as an agent for the dissemination of innovations by organizing seminars to update its members on the modifications in their subject area. Teachers should be encouraged to join and attend the meetings of the body to enhance their knowledge base. The authorities should also organize in-service training for teachers.

To the existence of inadequate teaching and learning resource, as revealed by the study, it is recommended that schools authorities, Parent-Teacher Associations (PTAs) and school's Board of Governors mobilize resources to make these facilities available to the schools for teachers to use.

\section{REFERENCES}

[1] (WAEC), T. W. A. E. C. (2003-2007). Chief Examiners Reports T. W. A. E. C. (WAEC)

[2] (WAEC), W. A. E. C. (2011). Chief Examiners' Reports. W. A. E. Council. https://www.waecgh.org/uploads/examinersReport/2011/Humaniti es.pdf

[3] Adelman, I. (2001). Fallacies in development theory and their implications for policy. Frontiers of development economics: The future in perspective, 103-134.

[4] Adentwi, K. (2005). Curriculum Development. In: An Introduction.

[5] Adentwi, K., \& Sarfo, F. (2005). Curriculum development: An introduction. Ghana: WILAS Press imited.

[6] Adjei, H., Baffoe, R. S., Ansah, C. A., \& Baffoe, M. S. (2013). The impact of teaching learning resources on teaching business management. Researchjournali's Journal of Education, 1(2), 1-10.

[7] Aggarwal, S., \& Jca, O. (2009). Principles, Methods \& Techniques Of Teac. Vikas Publishing House.

[8] Antwi, M. K. (1993). Teaching as a noble profession: Furture prospects for action. Journal of the Institute of Education, 2, 7-4.

[9] Atkins, M., \& Brown, G. (2002). Effective teaching in higher education. Routledge.

[10] Baynham, D., \& Trump, J. L. (1961). Focus on Change: Guide to Better Schools. Chicago: Rand McNally.

[11] Behlol, M. G., Akbar, R. A., \& Sehrish, H. (2018). Effectiveness of Problem Solving Method in Teaching Mathematics at Elementary Level. Bulletin of Education and Research, 40(1), 231-244.

[12] Block, R. A. (2014). Cognitive models of psychological time. Psychology Press.

[13] Cannon, H. M. (1987). From Theory to Practice: A model for teaching beginning advertising. Developments in Business Simulation and Experiential Learning: Proceedings of the Annual ABSEL conference,

[14] Carpenter, J. M. (2006). Effective teaching methods for large classes. Journal of Family \& Consumer Sciences Education, 24(2).

[15] Council, W. A. E. (2010). Chief examiners' report. Lagos: WAEC.

[16] Danaei, S. M., Zarshenas, L., Oshagh, M., \& Khoda, S. M. O. (2011). Which method of teaching would be better; cooperative or lecture? Iranian journal of medical education, 11(1).

[17] Dare, L. (1995). Towards a better understanding of school economics in Ghana: Some suggestions for action. The Oguaa Educator, 11(2), 34.

[18] Dotse, J. (1984). Methods in teaching social sciences. Unpublished work, 89.

[19] Farrant, J. S. (1964). Principles and practice of education. Longmans.

[20] Fleming, C. M. (2017). Teaching: a psychological analysis. Routledge.

[21] Gall, M. (1984). Synthesis of research on teachers' questioning. Educational leadership, 42(3), 40-47.

[22] Groenewegen, T. (1995). Educational Communications and Technology; Methods of Teaching Religious Education. In: Kenyatta University.

[23] Harbury, C., \& Szreter, R. (1970). The value of prior experience of economics for university students. The Journal of Economic 
Education, 2(1), 56-62.

[24] Harris, D. N., \& Sass, T. R. (2009). The effects of NBPTS-certified teachers on student achievement. Journal of Policy Analysis and Management: The Journal of the Association for Public Policy Analysis and Management, 28(1), 55-80.

[25] Heitzmann, W., \& Starpoli, C. (1975). Teacher characteristics and successful teaching. Education, 95(3).

[26] Howes, V. M. (1974). Informal teaching in the open classroom. MacMillan Publishing Company.

[27] Kuethe, J. L. (1968). The teaching-learning process. Scott, Foresman.

[28] L., D. (1993). Conference of Heads of Assisted Secondary Schools (CHASS). Daily Graphic.

[29] Lowman, J., \& Lowman, J. (1984). Mastering the techniques of teaching (Vol. 1990). Jossey-Bass San Francisco.

[30] Mabusela, S. P. (2018). The challenges of curriculum changes in teaching economic and management sciences in schools in the Umhlathuze circuit University of Zululand].

[31] Meyers, C. (1986). Teaching Students to Think Critically. A Guide for Faculty in All Disciplines. Jossey-Bass Higher Education Series. ERIC.

[32] Nacino-Brown, R., Oke, F. E., \& Brown, D. P. (1982). Curriculum and instruction: An introduction to methods of teaching. Macmillan Publishers Limited.

[33] Ojo, J. (2008). Student, teacher and school-related factor variables as correlate of senior secondary school students' achievement in English language. Unpublished Doctoral Thesis University of
Ibadan.

[34] Pologeorgis, N. (2002). Promoting economic literacy: An analysis of the effectiveness of economic education programs in $\mathrm{K}-12$ urban, suburban and rural schools. University of Missouri-Kansas City.

[35] Rogers, B. (2009). " Better" People, Better Teaching: The Vision of the National Teacher Corps, 1965-1968. History of Education Quarterly, 49(3), 347-372.

[36] Rubin, A., \& Babbie, E. R. (2016). Empowerment series: Research methods for social work. Cengage Learning.

[37] Smith, A. (1776). An inquiry into the nature and causes of the wealth of nations: Volume One. In. London: printed for W. Strahan; and T. Cadell, 1776.

[38] Strauss, R., \& Vogt, W. (2001). Effect of knowledge and pedagogy on students' achievement. A paper presented at the annual of educational finance.

[39] Swinton, J. R., De Berry, T., Scafidi, B., \& Woodard, H. C. (2010). Does in-service professional learning for high school economics teachers improve student achievement? Education Economics, 18(4), 395-405.

[40] Tamakloe, E., Amedahe, F., \& Atta, E. (2005). Effective methods of teaching. Accra: Black mask limited.

[41] Wallen, N. E., \& Fraenkel, J. R. (2013). Educational research: A guide to the process. Routledge.

[42] Wilen, W. W. (1990). Teaching and learning through discussion: The theory, research, and practice of the discussion method. Charles C Thomas Pub Limited. 